\title{
Synthesis of 5-Isopropyl-Substituted Poly(L-proline)s: Optically Active cis- and trans-5-Isopropylproline and Poly(cis- and trans-5-isopropylproline)
}

\author{
Dedicated to the Memory of the late Professor Ichiro Sakurada \\ K. A. W. MCGRADY and C. G. OVERBERGer \\ Department of Chemistry and the Macromolecular Research Center, \\ The University of Michigan, Ann Arbor, Michigan 48109 U.S.A.
}

(Received January 19, 1987)

\begin{abstract}
The present report describes our current efforts to determine the nature of the cis/trans isomerization observed for poly(L-proline). Previously, we examined the effect that a substituent in the 5-position of the pyrrolidine ring had on the preferred conformations of poly(Lproline). We concluded that a bulkier group was needed in order to see significant changes in the conformation of polyproline. Thus, the synthesis of optically active poly(cis- and trans-5isopropylproline) is described. The synthesis of the monomers involves the formation of $\Delta^{\prime}-2$ isopropylpyrroline-5-carboxylic acid hydrochloride (III) which is prepared|fromithe|Michael adduct obtained from the reaction of 1-chloro-4-methyl-3-pentanone with diethylacetamidomalonate. Catalytic hydrogenation of III gives the hydrochloride salt of cis-5-isopropylproline. The trans isomer is obtained through a chemical separation method that depends on difference in reactivity between the $c$ is and trans isomers to $p$-toluene sulfonyl chloride. The optical resolution of both isomers is carried out using fractional crystallization methods. Polymers of optically active cis- and trans-5-isopropylproline are obtained by ring-opening polymerization of the corresponding $\mathrm{N}$ carboxyanhydrides. Low yields encountered in the polymerization of poly(cis-5-isopropylproline) can be attributed to instability of the $N$-carboxyanhydride. The possibility that ring conformation may be seriously altered by the presence of a large group in the 5-position is briefly considered.

KEY WORDS Poly(L-proline)/Proline / Optical resolution / Conformation / Isomerism / Configuration / Ring-Opening Polymerization /
\end{abstract}

Of all the $\alpha$-amino acids, L-proline (Pro) is unique with respect to its behavior in naturally occurring proteins and peptides. ${ }^{1}$ Studies of many globular proteins have demonstrated that cis peptide bonds are virtually non-existant, except in cases where the X-Pro sequence occurs; here, either the cis or the trans conformation about the imide bond has been observed. $^{2-4} \mathrm{~A}$ major reason for this dual nature is that similar steric interactions occur for both forms. The difference in conformational freedom is not as great as it is with non-Pro residues because rotation is restricted by the pyrrolidine ring. Moreover, poly(L-proline) (PP) itself exists in one of two stable forms: form I, a right-handed helix with all cis amide bonds and form II, a lefthanded helix with all trans amide bonds. These forms occur both in the solid state and in solution. ${ }^{1,2,5}$ Polyproline changes its helical structure, form I to form II, through a cis-trans isomerization of the imide bond. The reverse process is also possible (form II to form I). ${ }^{3,4}$ A third, more random structure has also been observed for PP in concentrated salt solutions. ${ }^{5.6}$ Thus, the Pro peptide unit has generated considerable interest in the area of structural analysis of polypeptides and proteins because of its unique ability to exist in two forms. 
At one point, the isomerization of Pro residues was thought to be responsible for the slow kinetic step observed in protein renaturation. ${ }^{7}$ While this unique behavior or Pro residues is still recognized as being important in protein renaturation, more recent work has suggested that not all Pro residues behave in this manner, i.e., not all the residues block protein folding. ${ }^{8}$ Evidently, there are some "non-essential" residues that can isomerize after folding has taken place. In fact, Levitt has proposed the existence of three different types of proline residues in globular proteins: Type I residues which isomerize as freely when incorporated into native conformation as when in solution; Type II residues which destabilize the native conformation when in the "incorrect" isomeric form but not enough to block folding; and Type III residues which destabilize the native conformation sufficiently so that folding to the native-like conformation is impossible unless the proline residue has the correct isomeric form. ${ }^{9}$

Poly(L-poline) is also considered unusual because it maintains a helical structure in solution without hydrogen bonding. Steric factors should be critical in maintaining the helical conformation of PP since no amido hydrogen atoms are present for stabilization of the helix through hydrogen bonding. In this research group, a number of substituted prolines have been synthesized and their solution behavior studied in order to determine the effect of these alterations on the conformation and mutarotation of polyproline. For example, poly(2-methylproline) (P2MP) was found to exist only in a form II-type helix which did not mutarotate. ${ }^{10}$ When a methyl group was introduced to the 5-position of the pyrrolidine ring, both poly(cis-5-methylpoline) $(\mathrm{PC} 5 \mathrm{MP})^{11}$ and poly(trans-5-methylproline) $(\mathrm{PT} 5 \mathrm{MP})^{12,13}$ showed only small conformational changes when compared to unsubstituted PP. PT5MP, however, possessed an activation energy for mutarotation that was approximately $13 \mathrm{kcal} \mathrm{mol}^{-1}$ higher than that observed for unsubstituted PP. These results as a whole suggested that introduction of a substituent in the 5-position on the prolyl ring could lead to changes in preferred conformations. It was also anticipated that replacement of the methyl group with an ethyl group would cause even more pronounced effects. As in the case of PC5MP, the cis isomer of poly (5ethylproline) did not exhibit substantially different conformational behavior than its unsubstituted counterpart. The trans isomer (PT5EP), however, mutarotated from a form I-type helix to some intermediate conformation in which some of the amide bonds were in the trans conformation.

Nevertheless, conformational energy calculations had predicted that PT5EP would not mutarotate. Since we are interested in obtaining a species in which only one helical form exists as dictated by the substituent on the pyrrolidine ring, we decided that substitution of a group that was slightly more bulky than the ethyl group was needed. Thus, the synthesis of poly(cis- and trans-5-isopropylproline) was proposed. We are specifically interested in how rotational isomerism of the side chainisopropyl group affects the conformation and mutarotation of PP. It should be noted that this synthesis presents somewhat of a challenge to us since some difficulty was encountered in the polymerization of trans-5-ethylproline. The source of this difficulty is thought to be steric hindrance between the ethyl group and the anhydride moiety in trans-5-ethylproline $N$-carboxyanhydride.

\section{RESULTS AND DISCUSSION}

\section{Synthesis of cis- and trans-5-Isopropylproline}

At the time this work was undertaken, the synthesis of both stereoisomers of 5-isopropylproline had not been reported. However, synthetic routes to both cis- and trans-5ethylproline developed by Overberger and coworkers ${ }^{11,14,15}$ greatly facilitated the synthesis of the isopropyl derivatives. 

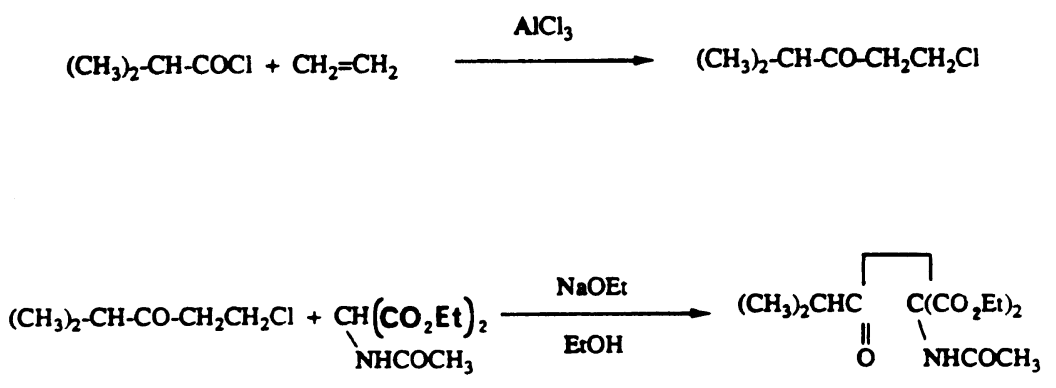

I

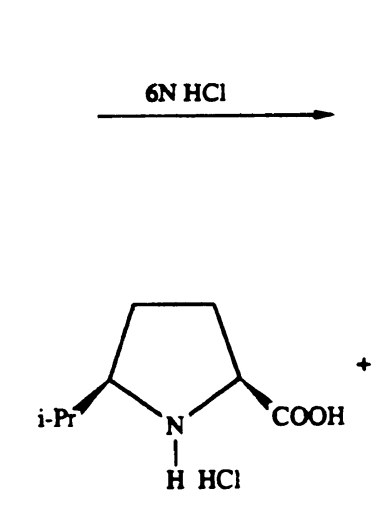

II

$\mathrm{NaBH}_{4}$<smiles>CCC[C@@H]1CC[C@@H](C(=O)O)N1[CH]Cl</smiles>

Scheme 1.

cis-5-Isopropylproline (C5IPP) (V) was prepared by catalytic hydrogenation of $\Delta^{\prime}-2$ isopropylpyrroline-5-carboxylic acid hydrochloride (III) which was prepared by ring closure of the Michael adduct (II) obtained by reacting 1-chloro-4-methyl-3-pentanone (I) with diethylacetamidomalonate (Scheme 1). The free amino acid was obtained by eluting an aqueous solution of the hydrochloride salt through a weakly basic ion exchange column (Amberlite IR-45).

Since we have not fully investigated the various types of catalysts that might preferentially lead to all trans isomer (T5IPP), this material was prepared by relying on an efficient separation method that was used in the case of trans-5-methylproline (Scheme 2). ${ }^{11}$ Reduction of III with sodium borohydride gave a 48:52 mixture of the cis and trans isomers as shown by integration of their respective $\delta$-proton NMR resonances. This particular proton is sensitive to the location of the isopropyl group relative to that of the carboxylic acid functionality on the ring. The chemical shift for this proton in the trans isomer is further upfield than it is in the cis isomer.

The difference in reactivity of the isomers to $p$-toluene sulfonyl chloride was used to separate the two isomers. The cis isomer forms a sulfonamide quite readily while the trans isomer reacts very slowly resulting first in the hydrolysis of the sulfonyl chloride in the aqueous solution. This selective reactivity was used to separate the diastereomers of 3-methylproline. ${ }^{16}$ The mixture of cis and trans-5isopropylproline was stirred with an equimolar amount of $p$-toluenesulfonylchloride in a water-acetone solution for $12 \mathrm{~h}$. The sulfonamide $\mathrm{V}$, containing predominantly the cis isomer, was extracted with ethyl acetate. The aqueous solution containing the $p$-toluenesulfonate salt of trans-5-isopropylproline was passed over a weakly basic ion ex- 

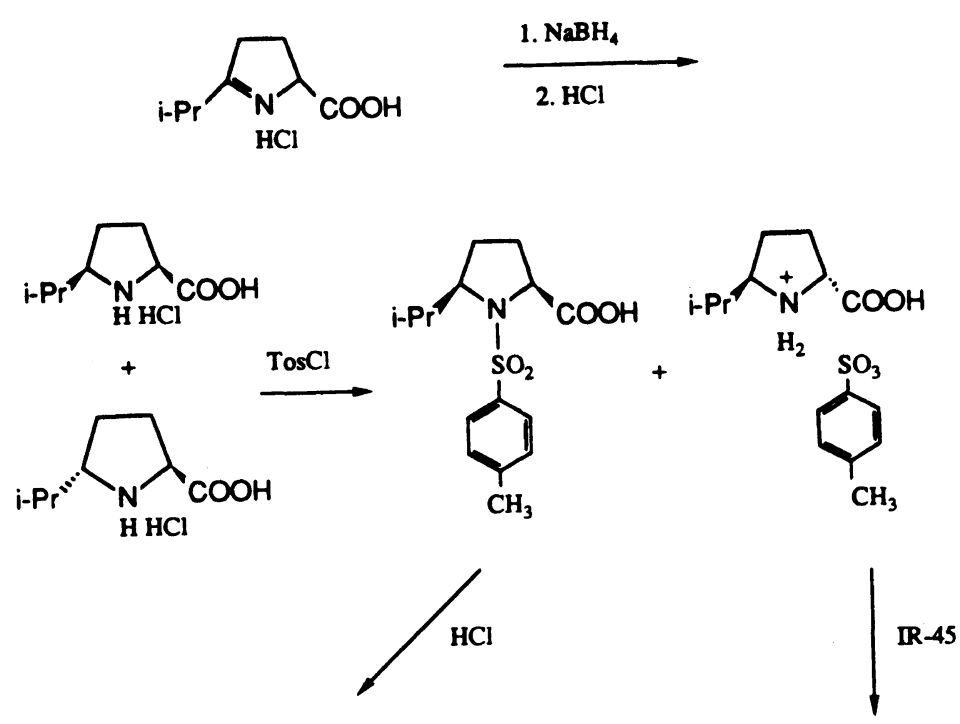<smiles>CCCC1CCC(C(=O)O)C1C(=O)O</smiles><smiles>O=C(O)[C@@H]1CC[C@@H](P)N1</smiles>

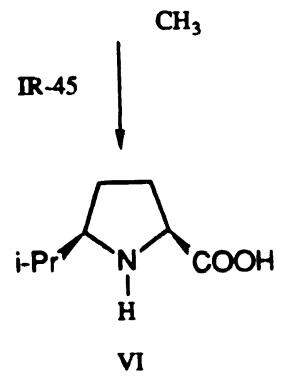

Scheme 2.

change resin (Amberlite IR-45). Compound VII, isolated by this method, had a sharp melting point. Proton NMR spectroscopy showed the complete absence of the cis isomer. It should be noted, however, that hydrolysis of sulfonamide $\mathrm{V}$ was not the method of choice used to isolate the cis isomer; this is due largely to the observation that after 3 days of hydrolysis in $6 \mathrm{~N} \mathrm{HCl}$ the cis isomer was isolated in yields of only $11 \%$. Moreover, proton NMR spectroscopy showed that this material was contaminated with approxi- mately $8 \%$ trans isomer.

The use of proton NMR spectroscopy to evaluate stereochemistry has replaced vapor phase chromatography and ${ }^{13} \mathrm{C}$ NMR spectroscopy-methods used previously to determine the relative stereochemistry of the substituents in the 2 and 5-positions. The $\delta$ proton resonance of the trans isomer is 0.1492 ppm upfield from that of the $c i$ isomer. ${ }^{13} \mathrm{C}$ NMR spectroscopy also serves as a suitable means of distinguishing the isomers, however, the spectra are usually much too 
complex to make this an easy method for identifying the isomers. Assignments of the carbon resonances in the ${ }^{13} \mathrm{C}$ NMR spectra of cis- and trans-5-isopropylproline were made by performing off-resonance decoupling experiments (Table I). The observed resonances can also be compared to calculated values which are determined using the additivity relationships established by Horsley and Sternlicht. ${ }^{17,18}$ Differences between the calculated values and the observed ones are largely due to the contribution of zwitterionic forms which have different chemical shift parameters.

The difference between the ${ }^{13} \mathrm{C}$ spectra of cis- and trans-5-isopropylproline is intriguing. Particularly noteworthy is the similarity of the $\beta$ - and $\gamma-\mathrm{C}$ resonances in the trans isomer. This phenomenon is not observed in the cis species. While it is difficult to predict conformation using ${ }^{13} \mathrm{C}$ NMR spectroscopy, it would be useful to have some understanding of how much influence a large, bulky group has on ring conformation in these substituted species since there is little doubt that ring conformation plays a significant role in the isomerization process described above (puckering of the ring at certain atoms, for example). In fact, it is possible that isomerization of the imide bond is prevented not so much by the bulkiness of the group in the 5-position, but rather, the variation in ring coformation as a result of the substitution. We are currently examining this problem more closely. Our studies also include evaluation of vicinal couplings as calculated from proton NMR spectra of these species. While this information cannot specify unique ring conformations, it would help to put limits on the types of acceptable conformations. The results of these studies will be presented at a later date.

Optical Resolution of cis- and trans-5-Isopropylproline

Previously, cis-5-ethylproline was resolved by the fractional crystallization method using
Table I. ${ }^{13} \mathrm{C}$ NMR spectral assignment for $c i s-$ and trans-5-isopropylproline

\begin{tabular}{lccccccc}
\hline Species & $\mathrm{CO}$ & $\mathrm{C}_{\alpha}$ & $\mathrm{C}_{\beta}$ & $\mathrm{C}_{\gamma}$ & $\mathrm{C}_{\delta}$ & $\mathrm{CH}$ & $\left(\mathrm{CH}_{3}\right)_{2}$ \\
\hline Proline & 175.2 & 62.3 & 29.9 & 24.8 & 47.2 & - & - \\
$\left(\mathrm{D}_{2} \mathrm{O}\right)$ & & & & & & & \\
C5IPP & 177.2 & 70.48 & 30.97 & 29.59 & 63.33 & 32.88 & 21.38 \\
$\left(\mathrm{D}_{2} \mathrm{O}\right)$ & & & & & & & 20.81 \\
T5IPP & 177.3 & 70.32 & 31.8 & 31.73 & 64.20 & 33.41 & 22.15 \\
$\left(\mathrm{D}_{2} \mathrm{O}\right)$ & & & & & & & 21.34 \\
\hline
\end{tabular}

$\mathbf{L}(+)$-tartaric acid as the resolving agent. A similar method was applied in the resolution of cis-5-isopropylproline with success, however, the yields of resolved material were quite low (18 and $26 \%$ for the $(+)$ and $(-)$ enantiomers, respectively). Alternatively, racemic C5IPP could be resolved using either (-)-dibenzoylL-tartaric acid monohydrate or its enantiomer, (+)-dibenzoyl-D-tartaric acid monohydrate. For some time, it has been known that 2,6pipecolic acid can be resolved, in its underivatized form, with L-tartaric acid. ${ }^{19}$ Use the underivatized species was considered advantageous given that formation of the methyl ester substantially reduces the overall yield of resolved material. Thus, an attempt was made to resolve cis-5-isopropylproline with $\mathrm{L}$ tartaric acid. Unfortunately, no crystalline material could be isolated. The idea that a higher molecular weight species is generally more cyrstalline prompted us to use a resolving agent of higher molecular weight, i.e., the dibenzoyl-tartaric acid series. Thus, a 2:1 diastereomeric salt of C5IPP and ( + ) dibenzoyl-D-tartaric acid was isolated from an acetone solution with ether (Scheme 3). Three recrystallizations of this material from ethanol and ether produced $1.455 \mathrm{~g}$ of the salt $(68 \%$ of the theoretical yield for one enantiomer). The specific rotation of this material in $a b-$ solute ethanol was $+38.47^{\circ}$. The levorotatory salt was isolated using (-)-dibenzoyl-L-tartaric acid monohydrate. Six recrystallizations from ethanol and ether produced $1.52 \mathrm{~g}$ of a $2: 1$ salt $(71 \%$ of the theoretical yield for 


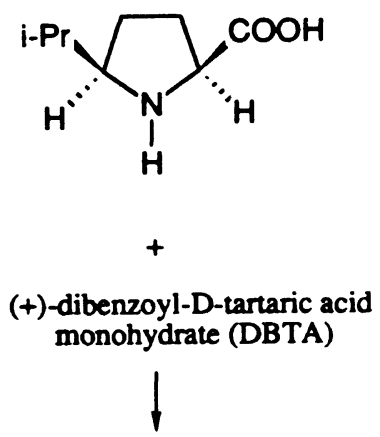

(t) 2:1 Salt C5IPP:DBTA

$D(+)[\alpha]_{D}+38.47^{\circ}$

(EtOH, $\mathrm{C}=1$ )

$3 \mathrm{~N} \mathrm{HCl}$<smiles>CCC[C@H]1CC[C@@H](C(=O)O)N1</smiles>

$D(+)[\alpha]_{D}+64.7^{\circ}$

$(\mathrm{MeOH}, \mathrm{C}=0.8$ )

$69 \%$<smiles>CCCC1NCCC1C(=O)O</smiles>

(-)-dibenzoyl-L-tartaric acid monohydrate (DBTA)

(-) 2:1 Salt C5IPP:DBTA

$L(-)[\alpha]_{D}-32.8^{\circ}$

(EtOH, C=1)

$3 \mathrm{~N} \mathrm{HCl}$<smiles>CCC[C@@H]1CC[C@H](C(=O)O)N1</smiles>

$L(-)[\alpha]_{D}-65.3^{\circ}$

(MeOH, C=0.9)

$77 \%$

Scheme 3.

one enantiomer). The specific rotation of this material was $-32.8^{\circ}$ in ethanol.

The enantiomers of cis-5-isopropylproline were obtained by first decomposing the $2: 1$ diastereomeric salts with $3 \mathrm{~N} \mathrm{HCl}$ and then pouring the resulting $\mathrm{HCl}$ salt over a column of Amberlite IR-45. Recrystallization procedures were carried out until no further change in the value for specific rotation could be detected. Optical purities were determined using the chiral shift reagent tris[3-(heptafluoropropylhydroxymethylene)- $d$ camphorato]europium (III), Eu(hfc) $)_{3}$. The use of chiral shift reagents in the determination of optical purities is well-known. ${ }^{20}$ The method involves the addition of the shift reagent in approximately a $1: 15$ molar ratio (shift reagent to compound) directly to the compound dissolved in a suitable solvent in the NMR tube. Any signal that is sufficiently separated from the others and which responds to the addition of the chiral shift reagent is deemed appropriate. The amide proton was observed to be the resonance most strongly affected by the addition of $\mathrm{Eu}(\mathrm{hfc})_{3}$. It was also found that the $(+)$ enantiomer of C5IPP shifted to higher fields than did the $(-)$ enantiomer upon the addition of the chiral shift reagent. These results suggest that the $(+)$ enantiomer coordinates preferentially to the shift reagent. It should be noted that we were unable to use the chiral shift reagent in solvents other than chloroform. Unfortunately, the free acid form of C5IPP is not soluble in this solvent. Thus, the L-tartaric acid method of resolving cis-5-isopropylproline methyl ester 


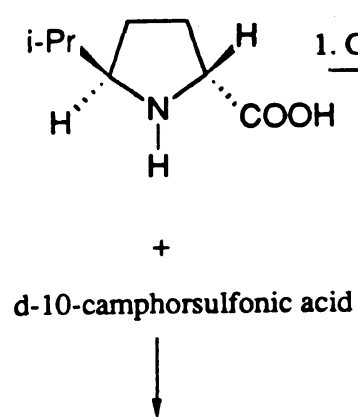

(+) $1: 1$ Salt

$D(+)[\alpha]_{D}+27.8^{\circ}$

$(\mathrm{MeOH}, \mathrm{C}=0.8)$

IR-45<smiles>CC(C)[C@H]1CC[C@@H](C(=O)O)N1</smiles>

$\mathrm{D}(+)[\alpha]_{D}+72.4^{\circ}$

( $\mathrm{MeOH}, \mathrm{C}=0.9$ )

$63 \%$<smiles>COC(=O)[C@H]1CC[C@@H](P)[C@H]1I</smiles>

1-tartaric acid<smiles>[3H][3H]</smiles>

(-) $1: 1$ Salt

$L(-)[\alpha]_{D}+6.08^{\circ}$

(MeOH, C=1)

1. $\mathrm{Na}_{2} \mathrm{CO}_{3}$

2. $\mathrm{H}_{2} \mathrm{O}$<smiles>O=C(O)[C@H]1CC[C@@H](P)N1</smiles>

$L(-)[\alpha]_{D}-73.9^{\circ}$

(MeOH, C=1)

$41 \%$

Scheme 4.

was employed (in spite of the fact that it gave such poor yields) to determine the optical purities of the enantiomers of C5IPP (and T5IPP). It should be noted that this is an indirect method of determining optical purities. The free acid material was obtained by hydrolyzing the methyl ester in weakly acidic water. Under these conditions, however, it is unlikely that much racemization occurs. Therefore, the values obtained for the specific rotation of the material after hydrolysis are most likely to be the absolute values provided the optical purity of the initial methyl ester was greater than $98 \%$.

The methods used to resolve trans-5ethylproline ${ }^{15}$ were applied with success to the case of trans-5-isopropylproline (Scheme 4). Thus, the dextrorotatory isomer was resolved using $d$-10-camphorsulfonic acid: (+)-T5IPP, $\mathrm{mp} 215-217^{\circ} \mathrm{C}$ (dec.), $[\alpha]_{\mathrm{D}}+72.3^{\circ}(\mathrm{MeOH}$, $\left.c=2.1 \mathrm{~g} \mathrm{dl}^{-1}\right)$. The levorotatory isomer was isolated by forming a diastereomeric salt between the methyl ester of (-)-T5IPP and unnatural $\mathrm{D}(-)$-tartaric acid (Scheme 4). The salt was decomposed and hydrolyzed under mild conditions to give (-)-T5IPP: $\mathrm{mp} 216$ $218^{\circ} \mathrm{C}$ (dec.), $[\alpha]_{\mathrm{D}}-73.9^{\circ} \quad(\mathrm{MeOH}, \quad c=1.0$ $\left.\mathrm{g} \mathrm{dl}^{-1}\right)$.

Absolute Configuration of cis- and trans-5Isopropylproline-Circular Dichroism Results

It is well known that circular dichroism (CD) can be used for the rapid assignment of absolute configuration of optically active $\alpha$ amino acids. ${ }^{21}$ The fact that all naturally oc- 
Table II. Selected data from the CD curves of cis- and trans-5-isopropylproline and L-proline

\begin{tabular}{|c|c|c|c|c|c|c|}
\hline \multirow{2}{*}{ Compound $^{a}$} & \multicolumn{2}{|c|}{$\mathrm{EtOH}$} & \multicolumn{2}{|c|}{$\mathrm{H}_{2} \mathrm{O}$} & \multicolumn{2}{|c|}{$\mathrm{HCl}(0.5 N)$} \\
\hline & {$[\Theta] \times 10^{-2}$} & $\lambda$ & {$[\Theta] \times 10^{-2}$} & $\lambda$ & {$[\Theta] \times 10^{-2}$} & $\lambda$ \\
\hline L-Proline & 9.6 & 214 & 2.75 & 211 & 6.5 & 207 \\
\hline$(+) \mathrm{C} 5 \mathrm{IPP}$ & $\begin{array}{l}18.8 \\
24.0\end{array}$ & $\begin{array}{l}198 \\
214\end{array}$ & $\begin{array}{l}26.2 \\
14.8\end{array}$ & $\begin{array}{l}197 \\
211\end{array}$ & $\begin{array}{l}45.1 \\
60\end{array}$ & $\begin{array}{l}204 \\
201\end{array}$ \\
\hline$(-)$ C5IPP & $\begin{array}{l}-19.4 \\
-23.9\end{array}$ & $\begin{array}{l}198 \\
214\end{array}$ & $\begin{array}{l}-25.9 \\
-14.8\end{array}$ & $\begin{array}{l}197 \\
211\end{array}$ & $\begin{array}{l}-45.7 \\
-60.1\end{array}$ & $\begin{array}{l}204 \\
201\end{array}$ \\
\hline$(+)$ T5IPP & $\begin{array}{l}-46.1 \\
-77.3\end{array}$ & $\begin{array}{l}214 \\
196\end{array}$ & $\begin{array}{r}-21.4 \\
23.8\end{array}$ & $\begin{array}{l}211 \\
196\end{array}$ & -23.5 & 208 \\
\hline$(-)$ T5IPP & 45.9 & $2 \cdot 14$ & 21.3 & 211 & 24 & 208 \\
\hline
\end{tabular}

a C5IPP $=$ cis-5-isopropylproline; T5IPP $=$ trans-5-isopropylproline.

curring and most synthetic $\mathrm{L}-\alpha$-amino acids show a positive Cotton effect around $200 \mathrm{~nm}$ in water and at $206-211 \mathrm{~nm}$ in aqueous acidic solutions makes use of this technique for this purpose possible. Table II shows selected data points from the CD curves of optically active cis- and trans-5-isopropylproline. Also shown are the wavelengths corresponding to the maxima found in the CD curve of L-proline. Both L-proline and (+)-C5IPP exhibit positive Cotton effects at $211-214 \mathrm{~nm}$ in ethanol and water. Thus, it is clear that (+)-C5TIPP belongs to the $\mathrm{L}-\alpha$-amino acid series. (-)-cis-5Isopropylproline, on the other hand, displays negative Cotton effects in these regions and is, therefore, assigned the D-configuration. The CD curves for the two enantiomers are almost identical except that the sign of ellipticity is opposite, as expected.

A similar type of analysis led to the conclusion that $(+)$-trans-5-isopropylproline possesses the D-configuration, while the (-)enantiomer belongs to the $L-\alpha$-amino acid series. It should be noted that the values for molecular ellipticity are considerably higher than those of L-proline. At this point, we are unable to explain this phenomenon.
Polymerization of cis- and trans-5-Isopropylproline

The polymers of optically active cis- and trans-5-isopropylproline were prepared ringopening reactions of their respective $\mathrm{N}$ carboxyanhydrides (Schemes 5 and 6, respectively). Unlike the $N$-carboxyanhydride (NCA) of cis-5-ethylproline, ${ }^{14}$ the NCA of $(+)$-C5IPP was found to be quite unstable. In fact, (+)-C5IPP-NCA was isolated in only $12 \%$. We suspect that the instability of this species is due to steric hindrance of the ring on the same side as the isopropyl substituent. Space-filling models confirm the existence of considerable steric hindrance in this portion of the molecule.

On the other hand, the $N$-carboxyanhydride of the trans isomer was obtained without any difficulty, in good yield $(71 \%)$ (Scheme 6). Nevertheless, as found in the case of trans-5ethylproline, ${ }^{15}$ the formation of $(+)$-T5IPPNCA required the use of more drastic conditions than those used for the $c i$ is isomer. This behavior might be rationalized by considering that the non-bonded occupied orbital of the cis-proline nitrogen has one completely unblocked side while that for the trans isomer is partially blocked on both sides of the plane of the ring. 

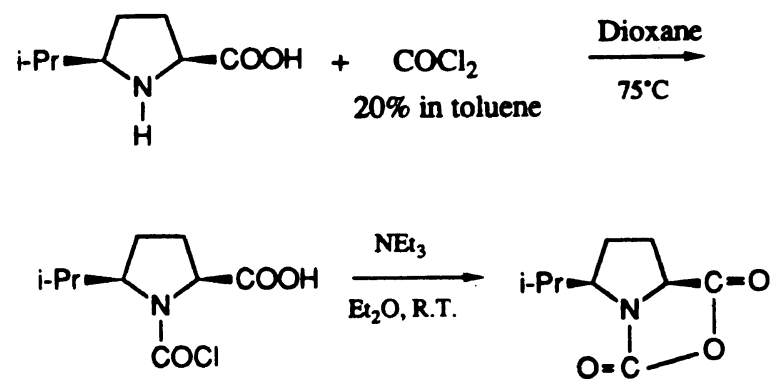

VIII: $[\alpha]_{D}+111.4^{\circ}\left(\mathrm{CCl}_{4}\right)$

IX: $[\alpha]_{D}-101.2^{*}\left(\mathrm{CCl}_{4}\right)$

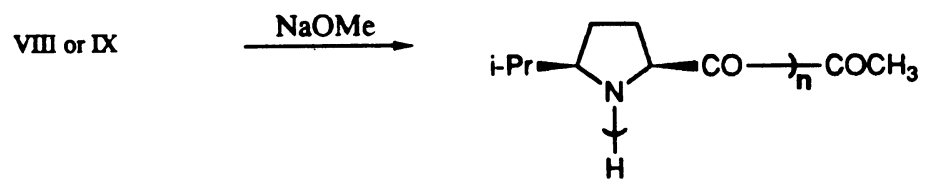

Scheme 5.
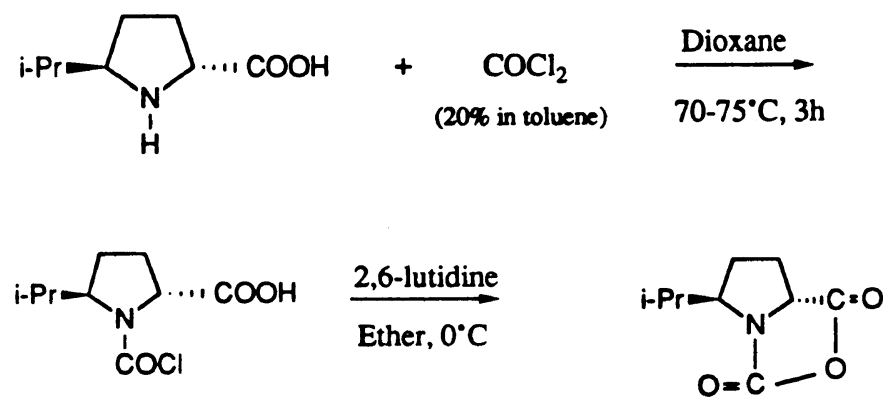

$\mathrm{X}:[\alpha]_{\mathrm{D}}+106.2^{\circ}\left(\mathrm{CCl}_{4}, c=1.0 \mathrm{~g} \mathrm{dl}^{-1}\right)$

$\mathrm{XI}:[\alpha]_{\mathrm{D}}-100.2^{\circ}\left(\mathrm{CCl}_{4}, c=0.97 \mathrm{~g} \mathrm{dl}^{-1}\right)$

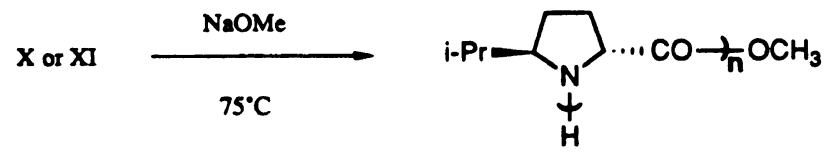

Scheme 6.

Polymerization of the optically active methylproline, ${ }^{11}$ polymerization of the NCA NCA's of both C5IPP and T5IPP was carried out using sodium methoxide as the initiator of T5IPP reported here requires more stringent (Table III). As was found in the case of conditions than those used for the polymerpolymerization of the NCA of trans-5ization of the cis isomer. 
Table III. Polymerization of optically active cis- and trans-5-isopropylproline $N$-carboxyanhydride

\begin{tabular}{|c|c|c|c|c|c|c|}
\hline \multirow{2}{*}{ Polymer $^{a}$} & \multirow{2}{*}{ Configuration } & \multirow{2}{*}{ Solvent } & \multirow{2}{*}{$\mathrm{NCA} / \mathrm{I}^{\mathrm{b}}$} & \multirow{2}{*}{$\frac{\text { Time }}{\mathrm{h}}$} & \multirow{2}{*}{$\frac{\text { Yield }}{\%}$} & \multirow{2}{*}{$\frac{[\eta]^{\mathrm{c}}}{\mathrm{dl} \mathrm{g}^{-1}}$} \\
\hline & & & & & & \\
\hline PT5IPP & $\mathrm{D}(+)$ & Melt & 5 & 2 & 30 & 0.1 \\
\hline PT5IPP & $\mathrm{D}(+)$ & Melt & 1 & 2 & 15 & 0.16 \\
\hline PC5IPP & $\mathbf{L}(-)$ & Melt & 5 & 2 & 17 & 0.15 \\
\hline PC5IPP & $\mathrm{D}(+)$ & Melt & 1 & 2 & 12 & 0.18 \\
\hline
\end{tabular}

a $\mathrm{PC} 5 \mathrm{IPP}=$ poly $($ cis-5-isopropylproline); $\mathrm{PT} 5 \mathrm{IPP}=$ poly $($ trans-5-isopropylproline $)$.

b NCA/I: mole ratio of NCA to sodium methoxide initiator.

c Viscosities at $26^{\circ} \mathrm{C}$ in dichloroacetic acid, concentration $=0.20 \mathrm{~g} \mathrm{dl}^{-1}$.

reaction was accompanied by the instantaneous evolution of $\mathrm{CO}_{2}$.

Isolation of the polymer was usually achieved by its precipitation into acetone and ether. It was also observed that precipitation into water also resulted in the isolation of polymeric material. In general, the polymers were powders, the solubilities of which appeared to be highly dependent on molecular weight. We are not certain at this point whether this difference in solubility is due to conformational changes in a given solvent. For example, low-molecular weight samples of poly(cis-5-isopropylproline) were soluble in chloroform and 2,2,2-trifluoroethanol (TFE). Higher molecular weight polymer only swelled in chloroform and was partially solvated in TFE. The low-molecular weight fraction of the trans polymer was also soluble in chloroform and TFE. For this isomer, alone, there was a fraction that was soluble in water ( $\mathrm{pH} \mathrm{6).} \mathrm{Higher-molecular} \mathrm{weight}$ fractions were only slightly soluble in chloroform even after a long period of time. These samples were also soluble in TFE. Other organic acids also solubilized this material.

These polymers are currently being further characterized. The results of these studies as well as those from an examination of the conformational behavior of these species in solution will be presented in a subsequent report.

\section{EXPERIMENTAL}

Reagent-grade chemicals were purified using conventional methods. Resolving agents were obtained either from the Sigma Chemical Company or the Aldrich Chemical Company, Inc. Ion-exchange resins, Amberlite IR-45 and IRA-45, were both obtained from the Morton Thiokol Company, Alfa Products division. ${ }^{22}$ Both resins could be regenerated by first treating them with a $1 \% \mathrm{HCl}$ solution followed by a $1 \% \mathrm{NaOH}$ solution. Phosgene solutions $(20 \%$ in toluene) were obtaind from the Fluka Chemical Corporation. Infrared spectra were recorded on a Nicolet 60-SX FT-IR spectrophotometer. Proton and ${ }^{13} \mathrm{C}$ NMR spectra were recorded either on a Bruker Model WM 360 or Bruker Model WM 300 NMR spectrometer. Unless otherwise noted, TMS or DSS were used as internal standards. Optical rotation measurements were taken at the sodium D line using a Perkin-Elmer Model 241 polarimeter with a $10-\mathrm{cm}$ cell, at room temperature. Circular dichroism plots were obtained using a JASCO Model J-40A spectropolarimeter with a $1-\mathrm{mm}$ cell, at room temperature. Concentrations were generally on the order of $0.1-1.0 \mathrm{mg} \mathrm{ml}^{-1}$. All measured temperatures are uncorrected and the melting points were determined using open capillary tubes, on a Thomas-Hoover capillary melting point apparatus. Solution vis- 
cosities of polymers were measured at $26 \pm$ $0.02^{\circ} \mathrm{C}$ in a Cannon-Ubbelhode viscometer tube with an automatic timer. Elemental analyses were performed either by Galbraith Laboratories, Inc. of Knoxville, Tennessee or by Spang Microanalytical Laboratory of Eagle Harbor, Michigan.

\section{Preparation of 1-Chloro-4-methyl-3-penta- none $(I)$}

To $360.02 \mathrm{~g}(2.7 \mathrm{~mol})$ of $\mathrm{AlCl}_{3}$ in $700 \mathrm{ml}$ of chloroform was added $252 \mathrm{~g}(2.36 \mathrm{~mol})$ of isobutyryl chloride. ${ }^{23}$ The resulting mixture was cooled to $-50^{\circ} \mathrm{C}$ with a dry-ice acetone slurry and ethylene was added over a period of $4 \mathrm{~h}$. The reaction mixture was then warmed to room temperature and poured into slurry of ice and $10 \% \mathrm{HCl}$. The aqueous and organic layers were separated and the chloroform evaporated under reduced pressure. The highly colored residue was distilled $\left(45^{\circ} \mathrm{C} / 4.5 \mathrm{mmHg}\right)$ to yield pure 1-chloro-4-methyl-3-pentanone, $211.13 \mathrm{~g}(66 \%)$, as a colorless liquid. NMR $\left(\mathrm{CDCl}_{3}\right) \delta 3.75\left(\mathrm{t}, 1 \mathrm{H},-\mathrm{CH}_{2} \mathrm{Cl}\right), 2.94(\mathrm{t}, 1 \mathrm{H}$, $\mathrm{CH}_{2} \mathrm{CH}_{2}$ ), 2.63 (septet, $1 \mathrm{H},\left(\mathrm{CH}_{3}\right)_{2} \mathrm{CH}$ ), and $1.2108 \mathrm{ppm}\left(\mathrm{d}, 6 \mathrm{H},\left(\mathrm{CH}_{3}\right)_{2}\right)$; IR (neat) 2973 $2877(\mathrm{CH}), 1716$ (carbonyl) 1385, 1368 (isopropyl $\mathrm{CH}), 1468\left(\mathrm{CH}_{2} \mathrm{CH}_{2}\right)$, and $670 \mathrm{~cm}^{-1}$ (C-Cl); Anal. Calcd for $\mathrm{C}_{6} \mathrm{H}_{11} \mathrm{OCl}$ : C, $53.55 \%$; $\mathrm{H}, 8.18 \%$; $\mathrm{Cl}, 26.37$. Found: C, $54.03 \% ; \mathrm{H}$, $8.25 \% ; \mathrm{Cl}, 27.16 \%$.

\section{Preparation of Ethyl-2-acetamido-2-carbo- ethoxy-5-oxo-6-methylheptanoate (II)}

Diethylacetamidomalonate $(57.51 \mathrm{~g}, 0.2 \dot{6} 5$ mol) was added to $85 \mathrm{ml}$ of ethanol in which $6.095 \mathrm{~g}(0.265 \mathrm{~mol})$ of sodium had been dissolved. 1-Chloro-4-methyl-3-pentanone $(71.10 \mathrm{~g}, 0.529 \mathrm{~mol})$ was added dropwise over a period of $2 \mathrm{~h}$ and the resulting mixture was stirred for $4 \mathrm{~h}$. Glacial acetic acid $(20 \mathrm{ml})$ was added to quench the reaction and ethanol was removed under reduced pressure. Crude semicrystalline II was solidified with a $1: 1$ mixture of methanol and ether to give $.141 .92 \mathrm{~g}$ $(85.17 \%)$ of white crystalline needles, $\mathrm{mp} 72$ $73.5^{\circ} \mathrm{C}$; NMR $\left(\mathrm{CDCl}_{3}\right) \delta 6.70($ broads, $1 \mathrm{H}$, $\mathrm{NH}$ ), 4.17-4.24 (quartet, $4 \mathrm{H},\left(\mathrm{CH}_{2} \mathrm{CH}_{3}\right)_{2}$ ), 2.52-2.57 (m, 3H, $\left.\mathrm{CH}_{2} \mathrm{CH}_{2}, \mathrm{C} \underline{\mathrm{H}}\left(\mathrm{CH}_{3}\right)_{2}\right)$, 2.35-2.40 (t, 2H, $\left.\mathrm{CH}_{2} \mathrm{CH}_{2}\right), 2.00(\mathrm{~s}, 3 \mathrm{H}$, $\left.\mathrm{COCH}_{3}\right), 1.20-1.25\left(\mathrm{t}, 6 \mathrm{H},\left(\mathrm{CH}_{2} \mathrm{CH}_{3}\right)_{2}\right)$, and $1.01-1.02 \mathrm{ppm}\left(\mathrm{d}, 6 \mathrm{H},\left(\mathrm{C}_{3}\right)_{2}\right) ; \mathrm{IR}(\mathrm{KBr})$ 3286 (NH), 2976 (aliphatic $\mathrm{CH}$ ), 1742, 1710 (carbonyl), 1650 (carbonyl and NH, amide I and amide II bands), and $1190 \mathrm{~cm}^{-1}$ (-C-(CO)-O-). Anal. Calcd for $\mathrm{C}_{15} \mathrm{H}_{25} \mathrm{NO}_{6}$ : C, $57.14 \%$;, $7.94 \%$; N, 4.44\%. Found: C, $56.98 \%$; H, $7.72 \%$; N, $4.25 \%$.

\section{Preparation of $\Delta^{\prime}-2-I$ sopropylpyrroline-5-car-} boxylic acid Hydrochloride (III)

Ethyl-2-acetamido-2-carboethoxy-5-oxo-6methylheptanoate $(141.92 \mathrm{~g}, 0.4505 \mathrm{~mol})$ was dissolved in $250 \mathrm{ml}$ of dichloromethane. The solution was added dropwise over a period of $4 \mathrm{~h}$ to 5 equivalents of refluxing $6 \mathrm{~N} \mathrm{HCl}$. This addition was performed at such a temperature that the dichloromethane was continuously distilled. The resulting solution was stirred at the elevated temperature overnight. The solution was evaporated to dryness under reduced pressure to remove excess hydrochloric acid. The crude product could be crystallized by the addition of acetone. Additional washings with acetone produced a.white powder identified as III $(75.89 \mathrm{~g}, 88 \%)$. While this material was now sufficiently clean for subsequent reactions, a small portion of it was recrystallized from methanol and acetone in order to obtain an analytically pure sample. This material had a melting point of $151-$ $153^{\circ} \mathrm{C}$; NMR (DMSO) $\delta 5.013-5.06(\mathrm{t}, 1 \mathrm{H}, \alpha-$ $\mathrm{CH}), 3.20-3.18$ (septet, $\left.1 \mathrm{H}, \quad\left(\mathrm{CH}_{3}\right)_{2} \mathrm{CH}\right)$, $2.50-2.49\left(\mathrm{~m}, 2 \mathrm{H}, \mathrm{CH}_{2}-\mathrm{CH}_{2}\right), 2.15-2.14(\mathrm{~m}$, $2 \mathrm{H}, \mathrm{CH}_{2} \mathrm{CH}_{2}$ ), and $1.18-1.21 \mathrm{ppm}$ (dd, $6 \mathrm{H}$, $\left.\left(\mathrm{CH}_{3}\right)_{2}\right)$; IR (KBr) 2980-2340 (superimposed $\mathrm{OH}, \mathrm{CH}$, and $\mathrm{N}-\mathrm{HCl}$ ), 1719 (carboxylate), $1664(\mathrm{C}=\mathrm{N}), 1451,(\mathrm{~N}-\mathrm{HCl})$, and $1223 \mathrm{~cm}^{-1}$ (-C-C(O)-O-). Anal. Calcd for $\mathrm{C}_{8} \mathrm{H}_{14} \mathrm{NO}_{2} \mathrm{Cl}$ : $\mathrm{C}, 50.14 \%$; H, 7.31\%; N, 7.31\%; Cl, $18.52 \%$. Found: C, $50.18 \%$; H, 7.36\%; N, 7.26\%; Cl, $18.62 \%$. 
Preparation of cis-5-Isopropylproline Hydrochloride (IV)

III $(24 \mathrm{~g}, 0.125 \mathrm{~mol})$ was dissolved in $48 \mathrm{ml}$ of water and hydrogenated over platinum oxide $(0.0944 \mathrm{~g})$ for $14 \mathrm{~h}$ at $15 \mathrm{psi}$. The catalyst was removed by filtration and the solution evaporated to dryness to yield a white powdery material. Recrystallization of this material from methanol and ether produced $22.25 \mathrm{~g}$ $(92 \%)$ of pure cis-5-isopropylproline hydrochloride, mp $210-213^{\circ} \mathrm{C}$ (dec.); NMR $\left(\mathrm{D}_{2} \mathrm{O}\right)$ $\delta 4.45(\mathrm{t}, 1 \mathrm{H}, \alpha-\mathrm{C} \underline{\mathrm{H}}), 3.38-3.36$ (quartet, $1 \mathrm{H}, \delta-\mathrm{C} \underline{\mathrm{H}}), 2.44(\mathrm{~m}, 1 \mathrm{H}, \beta-\mathrm{C} \underline{\mathrm{H}}), 2.28-2.26$ $\left(\mathrm{m}, 2 \mathrm{H}, \gamma-\mathrm{C} \underline{\mathrm{H}}, \mathrm{C} \underline{\mathrm{H}}\left(\mathrm{CH}_{3}\right)_{2}\right), 1.99(\mathrm{~m}, 1 \mathrm{H}, \beta-$ $\mathrm{CH}), 1.76-1.75(\mathrm{~m}, 1 \mathrm{H}, \gamma-\mathrm{C} \underline{\mathrm{H}}), 1.08-1.07(\mathrm{~d}$, $\left.3 \mathrm{H}, \mathrm{CH}_{3}\right)$, and $1.00-0.984 \mathrm{ppm}\left(\mathrm{d}, 3 \mathrm{H}, \mathrm{CH}_{3}\right)$; IR (KBr) 3100-2553 (OH, CH and $-\mathrm{NH}_{2}{ }^{+}$ superimposed), 1751 (carboxylate), 1466, 1458, 1403. $\left(-\mathrm{NH}_{2}{ }^{+}\right), 1389,1369$ (isopropyl $\mathrm{CH})$, and $1208 \mathrm{~cm}^{-1}(-\mathrm{C}-\mathrm{C}(\mathrm{O})-\mathrm{O})$. Anal. Calcd for $\mathrm{C}_{8} \mathrm{H}_{16} \mathrm{NO}_{2} \mathrm{Cl}$ : C, $49.63 \% ; \mathrm{H}, 8.27 \%$; $\mathrm{N}, 7.24 \%$; Cl, $18.33 \%$. Found: C, $49.49 \%$; $8.21 \%$; N $7.28 \%$; Cl, $18.24 \%$.

\section{Preparation of cis-5-Isopropylproline $(V)$}

IV $(22.25 \mathrm{~g}, 0.115 \mathrm{~mol})$ was dissolved in water and passed through a column of Amberlite IR-45, a weakly basic ion exchange resin in the hydroxyform. The free amino acid was eluted with water at pH 6. Crude 5isopropylproline was isolated after removal of the water under reduced pressure. Pure V, $\mathrm{mp} 198-201^{\circ} \mathrm{C}$ (dec.), was obtained upon recrystallization with methanol and ether. Yields of recovery were generally on the order of $96 \%(17.33 \mathrm{~g})$; NMR $\left(\mathrm{D}_{2} \mathrm{O}\right) \delta 4.12(\mathrm{~m}$, $1 \mathrm{H}, \alpha-\mathrm{CH}$ ), 3.32 (quartet, $1 \mathrm{H}, \delta-\mathrm{CH}$ ), 2.31 $(\mathrm{m}, 1 \mathrm{H}, \beta-\mathrm{CH}), 2.28(\mathrm{~m}, 1 \mathrm{H}, \gamma-\mathrm{CH}), 2.21-$ $2.15\left(\mathrm{~m}, 1 \mathrm{H}, \mathrm{CH}\left(\mathrm{CH}_{3}\right)_{2}\right), 1.95(\mathrm{~m}, 1 \mathrm{H}, \beta-$ $\mathrm{C} \underline{\mathrm{H}}), 1.63(\mathrm{~m}, 1 \mathrm{H}, \gamma-\mathrm{C} \underline{\mathrm{H}}), 1.06-0.998(\mathrm{~d}, 3 \mathrm{H}$, $\left.\mathrm{CH}_{3}\right)$, and $0.994-0.980 \mathrm{ppm}$ (d, $3 \mathrm{H}$, $\mathrm{CH}_{3}$ ); IR (KBr) 3489 (free NH), 3106-2362 (immonium salt), 1635 ( NH, carboxylate), 1576 (carboxylate), and $1401-1376 \mathrm{~cm}^{-1}$ (carboxylate). Anal. Calcd for $\mathrm{C}_{8} \mathrm{H}_{15} \mathrm{NO}_{2}$ : C, $61.15 \%$; H, 9.55\%; N, $8.92 \%$. Found: C,
$60.97 \% ; 9.47 \%, \mathrm{~N}, 8.85 \%$.

Preparation of cis- and trans-5-Isopropylproline Hydrochloride by Sodium Borohydride Reduction

III $(46.4 \mathrm{~g}, 0.24 \mathrm{~mol})$ and potassium carbonate $(36.8,0.26 \mathrm{~mol})$ were dissolved in $120 \mathrm{ml}$ of water. To this solution was added, dropwise, -10 to $0^{\circ} \mathrm{C}, 9.2 \mathrm{~g}(0.244 \mathrm{~mol})$ of sodium borohydride and $4 \mathrm{~g}(0.028 \mathrm{~mol})$ of potassium carbonate in $69 \mathrm{ml}$ of water. This mixture was stirred overnight, acidified with hydrochloric acid, and evaporated to dryness. Ethanol was added to the residue to extract the mixture of cis- and trans-5-isopropylproline hydrochloride. Integration of the NMR peaks corresponding to the $\delta$-proton in the cis and trans isomers revealed that the mixture consisted of $52 \%$ of the latter isomer and $48 \%$ of the former isomer.

Separation of cis- and trans-5-Isopropylproline

The crude mixture of the cis and trans isomers (approximately $32.74 \mathrm{~g}$ ) was dissolved in $85 \mathrm{ml}$ of water containing $45.88 \mathrm{~g}(0.543$ mol) of sodium bicarbonate. $p$-Toluenesulfon$\mathrm{yl}$ chloride $(32.24 \mathrm{~g}, 0.17 \mathrm{~mol})$ in $85 \mathrm{ml}$ of acetone was added dropwise over a period of $2 \mathrm{~h}$. The resulting solution was stirred overnight, the acetone evaporated, and the residue acidified with $6 N \mathrm{HCl}$. Ethyl acetate and an excess of water were used to separate the sulfonamide (VI) from the $p$-toluenesulfonate salt of trans-5-isopropylproline (VII). The latter salt was extracted with ethanol after the water was removed under reduced pressure. The residue from the removal of the ethanol was dissolved in water poured on a column of Amberlite IR-45 (hydroxy form), and eluted with water at $\mathrm{pH}$ 6. The solution was evaporated to dryness and the crude product purified by recrystallization from methanol and ether. The NMR spectrum of this material showed only one peak in the region where the $\delta-\mathrm{CH}$ resonance occurs, 
thereby indicating that $100 \%$ trans material was obtained by this method. Thus, trans-5isopropylproline, $\mathrm{mp} \quad 212-214^{\circ} \mathrm{C}$ (dec.), was obtained in $74 \%$ yield $(10.22 \mathrm{~g})$ based on the theoretical yield for one isomer; NMR $\left(\mathrm{D}_{2} \mathrm{O}\right) \delta 4.10(\mathrm{t}, 1 \mathrm{H}, \alpha-\mathrm{C} \underline{\mathrm{H}}), 3.42$ (quartet, $1 \mathrm{H}$, $\delta$ - $\mathrm{C}$ ) $), 2.39-2.45(\mathrm{~m}, 1 \mathrm{H}, \beta-\mathrm{CH}), 2.20$ $2.25(\mathrm{~m}, 1 \mathrm{H}, \gamma-\mathrm{CH}), 2.12-1.95(\mathrm{~m}, 1 \mathrm{H}, \beta-$ $\mathrm{C}-\mathrm{H}), 1.88-1.93\left(\mathrm{~m}, 1 \mathrm{H}, \mathrm{C} \underline{\mathrm{H}}\left(\mathrm{CH}_{3}\right)_{2}\right), 1.87-$ $1.73(\mathrm{~m}, 1 \mathrm{H}, \gamma-\mathrm{CH}), 1.07-1.05\left(\mathrm{~d}, 3 \mathrm{H}, \mathrm{CH}_{3}\right)$, and $0.992-0.973 \mathrm{ppm}$ (d, $\left.3 \mathrm{H}, \mathrm{CH}_{3}\right) ; \mathrm{IR}$ (KBr) 3400 (free NH), 3104-2339 (immonium salt), and 1635, 1590,1395, $1346 \mathrm{~cm}^{-1}$ (carboxylate). Anal. Calcd for $\mathrm{C}_{8} \mathrm{H}_{15} \mathrm{NO}_{2}$ : C, $61.15 \% ; \mathrm{H}, 9.55 \%$; N, $8.92 \%$. Found: C, $60.84 \%$; H, $9.51 \%$; N, $8.45 \%$.

\section{Resolution of cis-5-Isopropylproline}

(+)-cis-5-Isopropylproline (VIII). V (1 g, $6.37 \mathrm{mmol})$ and $2.397 \mathrm{~g}(6.37 \mathrm{mmol})$ of $(+)-$ dibenzoyl-D-tartaric acid monohydrate were suspended in $50 \mathrm{ml}$ of acetone. Dissolution was achieved after $4 \mathrm{~h}$ of stirring at room temperature. Precipitation of the dibenzoylD-tartaric acid salt of cis-5-isopropylproline occurred when the acetone solution was poured into a large excess of ether ( 250 $\mathrm{ml})$. Recrystallization of this material from ethanol and ether three times produced pure crystals of (+)-cis-5-isopropylproline- $(+)$ dibenzoyl-D-tartaric acid salt, IX, $1.455 \mathrm{~g}$ $(68 \%$ based on the theoretical yield for one enantiomer), mp $83-86^{\circ} \mathrm{C}$; NMR spectroscopy indicated that a $2: 1$ salt (C5IPP to dibenzoyl-D-tartaric acid) had been obtained; $[\alpha]_{\mathrm{D}}=+38.47^{\circ} \quad\left(\mathrm{EtOH}, c=1.0 \mathrm{~g} \mathrm{dl}^{-1}\right)$. Anal . Calcd for $\mathrm{C}_{34} \mathrm{H}_{44} \mathrm{~N}_{2} \mathrm{O}_{12}: \mathrm{C}, 60.71 \% ; \mathrm{H}, 6.55 \%$; $\mathrm{N}, 4.17 \%$. Found: C, $60.79 \%$; H, 6.57\%; N, $4.19 \%$.

Liberation of (+)-cis-5-isopropylproline was accomplished by dissolving the $(+) \mathrm{di}$ astereomeric salt $(0.70 \mathrm{~g}, 1.014 \mathrm{~mol})$ in $15 \mathrm{ml}$ of methylene chloride. To this stirred solution was slowly added aqueous $3 \mathrm{~N} \mathrm{HCl}$ and the resulting mixture was stirred for $2 \mathrm{~h}$. After extraction of the organic layer, the water layer was evaporated to dryness. The residue was then redissolved in water, poured over the weakly basic ion exchange resin, Amberlite IR-45, and eluted with water. Water was removed under reduced pressure and the residual solid was crystallized from methanol and ether. Five recrystallizations from this solvent resulted in the isolation of $0.242 \mathrm{~g}(69 \%)$ of pure $(+)$-cis-5-isopropylproline, mp $216-218^{\circ} \mathrm{C} ;[\alpha]_{\mathrm{D}}+64.7^{\circ}(\mathrm{MeOH}$, $\left.c=0.80 \mathrm{~g} \mathrm{dl}^{-1}\right)$; NMR $\left(\mathrm{D}_{2} \mathrm{O}\right) \delta 4.13(\mathrm{~m}, 1 \mathrm{H}$, $\alpha-\mathrm{C} \underline{\mathrm{H}}), 3.31$ (quartet, $1 \mathrm{H}, \delta-\mathrm{C} \underline{\mathrm{H}}), 2.31(\mathrm{~m}, 1 \mathrm{H}$, $\beta-\mathrm{CH}), 2.27(\mathrm{~m}, 1 \mathrm{H}, \gamma-\mathrm{CH}), 2.057-2.1412(\mathrm{~m}$, $\left.1 \mathrm{H}, \mathrm{C} \underline{\mathrm{H}}\left(\mathrm{CH}_{3}\right)_{2}\right), 1.95(\mathrm{~m}, 1 \mathrm{H}, \beta-\mathrm{C} \underline{\mathrm{H}}), 1.63(\mathrm{~m}$, $1 \mathrm{H}, \gamma-\mathrm{C}-\underline{\mathrm{H}}), 1.0523-0.9992\left(\mathrm{~d}, 3 \mathrm{H}, \mathrm{CH}_{3}\right)$, and $0.9923-0.9765 \mathrm{ppm}\left(\mathrm{d}, 3 \mathrm{H}, \mathrm{C}_{-}\right)$; IR $(\mathrm{KBr})$ 3482 (free $\mathrm{NH}$ ), 3100-2316 (immonium), 1635 (NH, carboxylic acid), 1574, and 1400$1380 \mathrm{~cm}^{-1}$ (carboxylic acid, isopropyl $\mathrm{CH}$ ). Anal. Calcd for $\mathrm{C}_{8} \mathrm{H}_{15} \mathrm{NO}_{2}: \mathrm{C}, 61.15 \% ; \mathrm{H}$, 9.55\%; N, 8.92\%. Found: C, 61.18\%, 9.65\%; $\mathrm{N}, 8.51 \%$.

(-)-cis-5-Isopropylproline (IX). IX was isolated following the approach used in the case of (+)-C5IPP. Thus, $1 \mathrm{~g}(6.37 \mathrm{mmol})$ of racemic C5IPP and $2.397 \mathrm{~g}(6.37 \mathrm{mmol})$. of (-)-dibenzoyl-L-tartaric acid monohydrate afforded $1.52 \mathrm{~g}(71 \%)$ of a $2: 1$ diastereomeric salt, $[\alpha]_{\mathrm{D}}-32.8^{\circ}\left(\mathrm{EtOH}, c=1.00 \mathrm{~g} \mathrm{dl}^{-1}\right), \mathrm{mp} 85-$ $89^{\circ} \mathrm{C}$. Liberation with aqueous $3 N \mathrm{HCl}$ gave the hydrochloride salt of $(-)$ C5IPP which, in turn, was converted into the free amino acid by eluting the material through a column of Amberlite IR-45. Evaporating the eluent to dryness and recrystallizing the residue three times with methanol and ether afforded $0.279 \mathrm{~g}$ (77\% based on the theoretical yield for one enantiomer) of (-)-cis-5-isopropylproline, $\mathrm{mp} \quad 211-214^{\circ} \mathrm{C}, \quad[\alpha]_{\mathrm{D}}-65.3^{\circ} \quad(\mathrm{MeOH}$, $c=0.9 \mathrm{~g} \mathrm{dl}^{-1}$ ). NMR and IR spectra of this material are nearly identical to those of (+)cis-5-isopropylproline. Anal. . Calcd for $\mathrm{C}_{8} \mathrm{H}_{15} \mathrm{NO}_{2}$ : C, $61.15 \% ; \mathrm{H}, 9.55 \% ; \mathrm{N}, 8.92 \%$. Found: C, $61.08 \%$; H, $9.51 \%$; N, $8.78 \%$. 


\section{Resolution of trans-5-Isopropylproline}

(+)-trans-5-Isopropylproline. Racemic T5IPP, 2.79 (17.8 mmol) was dissolved in $75 \mathrm{ml}$ of acetone. This mixture was warmed and $4.135 \mathrm{~g}$ ( $17.8 \mathrm{mmol})$ of $d$-10-camphor sulfonic acid in a small amount of acetone was added. After overnight cooling, crystals of the 1:1 salt were filtered. Five recrystallizations from acetone and petroleum ether $(1: 2)$ yielded $2.9 \mathrm{~g}$ $(84 \%$ of the theoretical yield for one enantiomer) or the diastereomeric salt of T5IPP and $d$-10-camphorsulfonic acid, mp $160-163^{\circ} \mathrm{C}$, $[\alpha]_{\mathrm{D}}+27.8^{\circ} \quad\left(\mathrm{MeOH}, \quad c=0.8 \mathrm{~g} \mathrm{dl}^{-1}\right) . \quad$ Anal. Calcd for $\mathrm{C}_{18} \mathrm{H}_{31} \mathrm{O}_{6} \mathrm{~S}: \mathrm{C}, 55.53 \%$; H, $7.92 \%$; $\mathrm{N}, 3.62 \%$; S, $8.23 \%$. Found: C, $55.54 \%$; $8.00 \%$; N, 3.63\%; S, $8.31 \%$.

A solution of $2 \mathrm{~g}(5.14 \mathrm{mmol})$ of the diastereomeric salt in $12 \mathrm{ml}$ of water was eluted through an ion exchange column packed with Amberlite IR-45 resin. Removal of the solvent from this procedure resulted in a solid which was dispersed with acetone and filtered to give $0.775 \mathrm{~g}(96 \%)$ of (+)-trans-5-isopropylproline, $\mathrm{mp} 215-217^{\circ} \mathrm{C}$ (dec.). Further recrystallization from methanol and ether afforded $0.805 \mathrm{~g}(63 \%)$ of $(+)-$ T5IPP; $[\alpha]_{\mathrm{D}}+72.3^{\circ}$ $\left(\mathrm{MeOH}, c=0.9 \mathrm{~g} \mathrm{dl}^{-1}\right)$; NMR $\left(\mathrm{D}_{2} \mathrm{O}\right) \delta 4.09(\mathrm{t}$, $1 \mathrm{H}, \alpha-\mathrm{C} \underline{\mathrm{H}}$ ), 3.43 (quartet, $1 \mathrm{H}, \delta-\mathrm{CH}$ ), 2.40 $2.45(\mathrm{~m}, 1 \mathrm{H}, \beta-\mathrm{CH}), 2.20-2.24(\mathrm{~m}, 1 \mathrm{H}, \gamma-$ $\mathrm{CH}), 2.02-1.93(\mathrm{~m}, 1 \mathrm{H}, \beta-\mathrm{C} \underline{\mathrm{H}}), 1.87-1.93$ $\left(\mathrm{m}, 1 \mathrm{H}, \mathrm{CH}\left(\mathrm{CH}_{3}\right)_{2}\right), 1.86-1.72(\mathrm{~m}, 1 \mathrm{H}, \gamma-$ $\mathrm{C} \underline{\mathrm{H}}), 1.07-1.05\left(\mathrm{~d}, 3 \mathrm{H}, \mathrm{CH}_{3}\right)$, and $0.991-$ 0.973 ppm (d, $3 \mathrm{H}, \mathrm{CH}_{3}$ ); IR (KBr) 3400 (free NH), 3100-2445 (immonium salt), 1637, 1590, 1394, 1346 (carboxylate), and 1380, $1368 \mathrm{~cm}^{-1}$ (isopropyl $\mathrm{CH}$ ). Anal. Calcd for $\mathrm{C}_{8} \mathrm{H}_{15} \mathrm{NO}_{2}$ : C, 61.15\%; H, 9.55\%; N, 8.92\%. Found: C, $61.18 \%$; H, 9.52\%; N, $8.89 \%$.

(-)-trans-5-Isopropylproline. Hydrogen chloride gas was bubbled through a solution of racemic T5IPP $(9.357 \mathrm{~g}, 0.0596 \mathrm{~mol})$, in methanol, at $0-5^{\circ} \mathrm{C}$. After overnight stirring, the solution was repeatedly evaporated to dryness and diluted with methanol. The residual solid was recrystallized from methanol and ether $(1: 1)$ to yield $6.67 \mathrm{~g}(54 \%)$ of trans-5-iso- propylproline methyl ester hydrogen chloride, $\mathrm{mp} 148-150^{\circ} \mathrm{C}$; NMR $\left(\mathrm{D}_{2} \mathrm{O}\right) \delta 3.81-$ $3.85(\mathrm{t}, 1 \mathrm{H}, \alpha-\mathrm{C} \underline{\mathrm{H}}), 3.73\left(\mathrm{~s}, 3 \mathrm{H}, \mathrm{COC}_{3}\right)$, $2.87-2.89(\mathrm{~m}, 1 \mathrm{H}, \delta-\mathrm{CH}), 2.20-2.23(\mathrm{~m}, 1 \mathrm{H}$, $\beta-\mathrm{C} \underline{\mathrm{H}}), 1.85-1.91(\mathrm{~m}, 2 \mathrm{H}, \gamma-\mathrm{C} \underline{\mathrm{H}}, \beta-\mathrm{CH})$, $1.42-1.50(\mathrm{~m}, 2 \mathrm{H}, \mathrm{C} \underline{\mathrm{H}}, \gamma-\mathrm{C} \underline{\mathrm{H}}), 0.955-0.978$ (isopropyl $\mathrm{CH}_{3}$ ), and $0.866-0.889 \mathrm{ppm}$ (isopropyl $\mathrm{CH}_{3}$ ). Anal. Calcd for $\mathrm{C}_{9} \mathrm{H}_{18} \mathrm{NO}_{2} \mathrm{Cl}$ : C, $52.06 \%$ : H, 8.68\%; N, 6.75\%; Cl, $17.09 \%$. Found: $\mathrm{C}, 51.88 \% ; \mathrm{H}, 8.78 \% ; \mathrm{N}, 6.95 \% ; \mathrm{Cl}$, $16.97 \%$.

To a dispersion of the trans-5-isopropylproline methyl ester hydrochloride $(6.67 \mathrm{~g}, 0.0322 \mathrm{~mol})$ in $100 \mathrm{ml}$ of ether was added, dropwise, $4.488 \mathrm{ml}(0.0322 \mathrm{~mol})$ of triethylamine. The mixture was stirred for $4 \mathrm{~h}$, cooled overnight, and the precipitated triethyl ammonium hydrochloride salt removed by filtration. After removal of the ether under reduced pressure, yellowish trans-5-isopropylproline methyl ester was obtained in $58 \%$ yield. Some portions of the ester crystallized over several days; NMR $\left(\mathrm{CDCl}_{3}\right)$ $\delta 3.81-3.85(\mathrm{t}, 1 \mathrm{H}, \alpha-\mathrm{C} \underline{\mathrm{H}}), 3.73(\mathrm{~s}, 3 \mathrm{H}$, $\mathrm{COC}_{3}$ ), 3.42 (quartet, $1 \mathrm{H}, \delta-\mathrm{C} \underline{\mathrm{H}}$ ), 2.87-2.89 $(\mathrm{m}, 1 \mathrm{H}, \beta-\mathrm{CH}), 2.2(\mathrm{~m}, 1 \mathrm{H}, \gamma-\mathrm{C} \underline{\mathrm{H}}), 1.86-1.90$ $\left(\mathrm{m}, 2 \mathrm{H}, \beta-\mathrm{CH}, \mathrm{C} \underline{\mathrm{H}}\left(\mathrm{CH}_{3}\right)_{2}\right), 1.42-1.50(\mathrm{~m}, 1 \mathrm{H}$, $\gamma-\mathrm{C} \underline{\mathrm{H}}), \quad 0.954-0.973\left(\mathrm{~d}, 3 \mathrm{H}, \quad \mathrm{CH}_{3}\right)$, and $0.885-0.866 \mathrm{ppm}\left(\mathrm{d}, 3 \mathrm{H}, \mathrm{CH}_{3}\right)$.

To a solution of racemic trans-5-isopropylproline methyl ester $(3.19 \mathrm{~g}, 18.65$ $\mathrm{mmol}$ ) in $15 \mathrm{ml}$ of methanol and $15 \mathrm{ml}$ of acetone was added $2.799 \mathrm{~g}(18.65 \mathrm{mmol})$ of $\mathrm{D}$ ( - -) tartaric acid. The solution was heated to a temperature just below reflux for $10 \mathrm{~min}$. Upon cooling, crystals of the diastereomeric salt were isolated. During six recrystallizations zations from methanol and acetone, the specific optical rotation and the melting points gradually increased and reached nearly constant values. Thus, the 1:1 diastereomeric salt of ( - -T5IPP/( $)$-tartaric acid was obtained in $84 \%$ yield based on the theoretical yield for one enantiomer $(2.514 \mathrm{~g})$; $\mathrm{mp} \quad 79-81^{\circ} \mathrm{C}$; $[\alpha]+6.08^{\circ}\left(\mathrm{MeOH}, c=1.1 \mathrm{~g} \mathrm{dl}^{-1}\right)$. Anal. Calcd for $\mathrm{C}_{13} \mathrm{H}_{23} \mathrm{NO}_{8}: \mathrm{C}, 48.60 \% ; \mathrm{H}, 7.17 \% ; \mathrm{N}$, 
$4.36 \%$. Found: $\mathrm{C}, 48.68 \% ; \mathrm{H}, 7.16 \% ; \mathrm{N}$, $4.21 \%$.

The following procedure was employed to liberate (-)-T5IPP: the diastereomeric salt $(2 \mathrm{~g}, 6.23 \mathrm{mmol})$ was dissolved in $15 \mathrm{ml}$ of water and $20 \mathrm{ml}$ of methylene chloride to extract the (-) T5IPP methyl ester liberated from the subsequent decomposition of the $(-)$ salt. To the stirred mixture cooled with ice water was slowly added $0.66 \mathrm{~g}(6.23 \mathrm{mmol})$ of sodium carbonate. The resulting reaction mixture was stirred for $3 \mathrm{~h}$ at the low temperature. The organic layer was separated while cool and the methylene chloride evaporated under reduced pressure to give liquid (-)-trans-5isopropylproline methyl ester. The ester was mixed with $15 \mathrm{ml}$ of water. Complete hydrolysis of the ester was observed after $3 \mathrm{~d}$ at room temperature.

The solution was concentrated under reduced pressure and the residual crystalline materials recrystallized with methanol and ether $(1: 1)$ to afford $0.401 \mathrm{~g}(41 \%)$ of $(-)$ T5IPP, mp $215-217.5^{\circ} \mathrm{C}\left(\right.$ dec.); $[\alpha]_{\mathrm{D}}-73.9^{\circ}$ ( $\mathrm{MeOH}, c=1.0 \mathrm{~g} \mathrm{dl}^{-1}$ ); NMR and IR spectra of this species are nearly identical to those of (+)-T5IPP. Anal. Calcd for $\mathrm{C}_{8} \mathrm{H}_{15} \mathrm{NO}_{2}: \mathrm{C}$, $61.15 \%$; H, 9.55\%; N, 8.92\%. Found: C, $61.01 \%$; H, 9.57\%; N, 8.98\%.

\section{Preparation of (+)-cis-5-Isopropylproline $N$-Carboxyanhydride (VIII)}

The $N$-carboxyanhydride (NCA) of $(+)$ C5IPP (VIII) was prepared according to the method of Randall ${ }^{24}$ with the following modifications: $1.23 \mathrm{~g}$ (7.83 mmol) of (+)-C5IPP was suspended in $40 \mathrm{ml}$ of dry 1,4-dioxane. Phosgene $(1.5488 \mathrm{~g}, 0.01566 \mathrm{~mol})$ as a $20 \%$ solution in toluene was added dropwise and the suspension was heated to $75^{\circ} \mathrm{C}$ under nitrogen flow. After $4 \mathrm{~h}$, the mixture became a clear solution. The solvent was evaporated, and the residual liquid was repeatedly diluted with ether and evaporated to remove excess phosgene. The resulting residue was suspended in $50 \mathrm{ml}$ of ether, cooled with ice water and triethylamine $(1.09 \mathrm{ml}, 7.83 \mathrm{mmol})$ added to it dropwise. Triethylammonium hydrochloride precipitated after $1 \mathrm{~h}$ and the mixture was stirred for 3 more hours at room temperature. The salt was removed by filtration and the filtrate concentrated under reduced pressure to give (+)-cis-5-isopropylproline $N$-carboxyanhydride in $12 \%$ yield $(0.172 \mathrm{~g})$, as a yellowish viscous liquid; $[\alpha]_{D}=+111.4^{\circ}\left(\mathrm{CCl}_{4}, c=\right.$ $\left.1.04 \mathrm{~g} \mathrm{dl}^{-1}\right)$; NMR $\left(\mathrm{CDCl}_{3}\right): \delta 4.1-4.05(\mathrm{t}$, $1 \mathrm{H}, \alpha-\mathrm{CH}$ ), 4.0-3.9 (quartet, $1 \mathrm{H}, \delta-\mathrm{CH}$ ), $2.55-1.60\left(\mathrm{~m}, \quad 5 \mathrm{H}, \quad \beta-\mathrm{CH}_{2}, \gamma-\mathrm{C}_{2}, \quad \mathrm{C} \underline{\mathrm{H}}\right)$, $1.1-0.8\left(\mathrm{dd}, 6 \mathrm{H},\left(\mathrm{CH}_{3}\right)_{2}\right)$; IR (neat) 1780 and $1850 \mathrm{~cm}^{-1}$ (anhydride).

\section{Preparation of (-)-cis-5-Isopropylproline} $N$-Carboxyanhydride (IX)

The $N$-carboxyanhydride of (-)-C5IPP, (-)-C5IPP-NCA (IX), was prepared according to the procedure described above for the synthesis of (+)-C5IPP-NCA. Thus, from the reaction of $1.5 \mathrm{~g}(9.55 \mathrm{mmol})$ of $(-) 5-$ isopropylproline and $0.891 \mathrm{~g}(9.55 \mathrm{mmol})$ of phosgene as a $20 \%$ solution in toluene was obtained $0.215 \mathrm{~g}(15 \%)$ of (-)-C5IPP-NCA, $[\alpha]_{\mathrm{D}}-101.2^{\circ}\left(\mathrm{CCl}_{4}, c=0.821 \mathrm{~g} \mathrm{di}^{-1}\right)$. The IR and NMR spectra were found to be nearly identical to those of (+)-C5IPP-NCA.

\section{Preparation of (+)-trans-5-Isopropylproline} $N$-Carboxyanhydride $(X)$

To a suspension of $2 \mathrm{~g}(12.93 \mathrm{mmol})$ of $(+)-$ T5IPP in $65 \mathrm{ml}$ of freshly distilled 1,4-dioxane was added 1.9 equivalents $(2.433 \mathrm{~g})$ of phos: gene $(12.22 \mathrm{~g}$ of a toluene solution $20 \%$ in phosgene). A clear solution was obtained when the mixture was heated to $73^{\circ} \mathrm{C}$ for $3 \mathrm{~h}$. Excess phosgene was removed under reduced pressure by repeatedly dissolving in ether the residue from evaporation of all solvents and removing the ether.

The residue was then suspended in $50 \mathrm{ml}$ of ether, cooled with ice water, and $1.39 \mathrm{~g}$ (12.9 mmol, $1.5 \mathrm{ml})$ of 2,6-lutidine was added. This mixture was stirred under nitrogen flow for $4 \mathrm{~h}$, cooled overnight, and the 2,6-lutidine 
hydrochloride salt filtered.

The ether was removed under reduced pressure to yield $1.85 \mathrm{~g}(78 \%)$ of a brown liquid which was identified using ${ }^{1} \mathrm{H}$ NMR and IR spectroscopies. Purification of $\mathrm{X}$ involved eluting it through a silica gel column using a mixed solvent of ethyl acetate and hexane $(3: 2)$. The clear liquid $(1.68 \mathrm{~g}, 71 \%$ ), which was obtained upon removal of the solvents, had a specific rotation of $+106.2^{\circ}\left(\mathrm{CCl}_{4}, \quad c=1.0 \mathrm{~g} \mathrm{dl}^{-1}\right)$; NMR $\left(\mathrm{CDCl}_{3}\right) \delta 4.21(\mathrm{t}, 1 \mathrm{H}, \alpha-\mathrm{C} \underline{\mathrm{H}}), 3.90$ (quartet, $1 \mathrm{H}, \delta-\mathrm{CH}), 2.52-1.64(\mathrm{~m}, 5 \mathrm{H}, \gamma-$ $\left.\mathrm{C}_{2}, \beta-\mathrm{CH}_{2}, \mathrm{CH}\right)$, and $0.834-0.962 \mathrm{ppm}(\mathrm{dd}$, $\left.6 \mathrm{H},\left(\mathrm{CH}_{3}\right)_{2}\right) ; \mathrm{IR}$ (neat) 1780 and $1854 \mathrm{~cm}^{-1}$ (anhydride).

\section{Preparation of (-)-trans-5-Isopropylproline}

$N$-Carboxyanhydride $(X I)$

The $N$-carboxyanhydride of (-)-T5IPP, (-)-T5IPP-NCA (XI) was prepared following the procedure described above for the synthesis of (+)-T5IPP-NCA. Thus, the reaction of $2 \mathrm{~g}(12.93 \mathrm{mmol})$ of (-)-T5IPP and $2.5576 \mathrm{~g}(25.86 \mathrm{mmol})$ of phosgene as a $20 \%$ solution afforded $1.73 \mathrm{~g}(73 \%)$ of crude $(-)$ T5IPP-NCA. Uncontaminated (-)-T5IPPNCA was obtained when the crude material was eluted through a silica gel column using ethyl acetate-hexane $(3: 2)$. Removal of the solvent gave $1.585 \mathrm{~g}(67 \%)$ of clean (-)T5IPP-NCA, $[\alpha]_{\mathrm{D}}-100.2^{\circ}\left(\mathrm{CCl}_{4}, c=0.9725\right.$ $\left.\mathrm{g} \mathrm{dl}^{-1}\right)$; IR and NMR spectra were nearly identical to those of $(+)$-T5IPP-NCA.

\section{Polymerization of $\mathrm{N}$-Carboxyanhydrides of Optically Active cis- and trans-5-Isopropyl- proline}

The general procedure used to polymerize the $N$-carboxyanhydrides of cis- and trans-5isopropylproline is illustrated by the following description of the polymerization of $(+)$ T5IPP-NCA: $1-2 \mathrm{~g}$ of the NCA was placed in a glass tube which had previously been thoroughly dried and degassed. A catalytic amount of the initiator, sodium methoxide, was introduced to the tube under nitrogen flow. The tube was then placed in an oil bath, at $75^{\circ} \mathrm{C}$. After approximately $2 \mathrm{~h}$, a small amount of methanol was added to solubilize the materials and the whole was poured into a large excess of ether to precipitate the polymer. The polymer was filtered, washed with acetone and ether, and freeze-dried for $3 \mathrm{~d}(10 \mathrm{mT}$ Torr, $\left.-60^{\circ} \mathrm{C}\right)$.

The procedure used to polymerize the NCA's of the cis isomers was identical to that described above with the exception that the oil bath temperature was $55^{\circ} \mathrm{C}$. The primary means of determining the presence of polymer has been IR spectroscopy. A band at approximately $1650 \mathrm{~cm}^{-1}$ appears to be indicative of the formation of polymer.

\section{REFERENCES AND NOTES}

1. L. Mandelkern, "Poly- $\alpha$-amino Acids," G. D. Fasman, Ed., Marcel Dekker, Inc., New York, 1967, p. 675 .

2. D. S. Clark, J. J. Dechter, and L. Mandelkern, Macromolecules, 12, 626 (1979); ibid., 13, 533 (1980).

3. G. N. Ramachandran and A. K. Mitra, J. Mol. Biol., 107, 85 (1976).

4. S. S. Zimmerman and H. A. Scheraga, Macromolecules, 9, 408 (1976).

5. M. L. Tiffany and S. Krimm, Biopolymers, 6, 1767 (1968).

6. L. Mandelkern and W. L. Mattice, "Conformation of Biological Macromolecules and Polymers," E. D. Bergmann and B. Pullman, Ed., Jerusalem Symp. Quantum Chem. Bio-Chem., 5, 121 (1973).

7. J. F. Brandts, M. Brennan, and L. N. Lin., Proc. Natl. Acad. Sci. U.S.A., 74, 4178 (1977).

8. F. X. Schmid and R. L. Baldwin, Proc. Natl. Acad. Sci. U.S.A., 75, 4764 (1978).

9. M. Levitt, J. Mol. Biol., 145, 251 (1981).

10. C. G. Overberger and Y. S. Jon, J. Polym. Sci., Polym. Chem. Ed., 15, 1413 (1977).

11. C. G. Overberger and K.-H. David, and J. A. Moore, Macromolecules, 5, 368 (1972); C. G. Overberger and K.-H. David, Macromolecules, 5, 373 (1972).

12. C. G. Overberger and M. J. Han, J. Polym. Sci., Polym. Chem. Ed., 13, 2251 (1975).

13. C. G. Overberger and M. J. Han, J. Polym. Sci., Polym. Symp., 51, 155 (1975).

14. W. W.-Y. Yang, C. G. Overberger, and C. M. - Venkatachalam, J. Polym. Sci., Polym. Chem. Ed., 21, 1643 (1983); ibid., 21, 1741 (1983); ibid., 21, 1751 (1983).

15. K.-D. Ahn and C. G. Overberger, J. Polym. Sci., 


\section{5-Isopropyl-Substituted Polyprolines}

Polym. Chem. Ed., 21, 1699 (1983).

16. F. Irreverre, A. B. Mauger, and B. Witkop, J. Am. Chem. Soc., 87, 4875 (1965).

17. W. J. Horsley and H. Sternlicht, J. Am. Chem. Soc., 90, 3738 (1968).

18. W. J. Horsley, H. Sternlicht, and J. S. Cohen, J. Am. Chem. Soc., 92, 680 (1970).

19. H. C. Beyerman, Rec. Trav. Chim., 78, 134 (1959).

20. R. E. Sievers (Ed), "Nuclear Magnetic Resonance Shift Reagents," Academic Press, New York, 1973, p 87.

21. E. Jizuka and J. T. Yang, Biochemistry, 13, 1519
(1964).

22. Recently, it was brought to our attention that both Amberlite IR-45 and IR-45 are no longer commercially available. We are currently investigating the possibility of using other ion exchange resins that are specifically designed for the removal of strong acids.

23. A. I. Vogel, "A Textbook of Practical Organic Chemistry," 3rd ed, J. Wiley and Sons, New York, 1962, p 368.

24. A. A. Randall, J. Chem. Soc., 374 (1962). 